\title{
Comparison of oxygen microgradients, oxygen flux rates and electron transport system activity in coastal marine sediments
}

\author{
Frede Østergaard Andersen ${ }^{1} \&$ Willem Helder ${ }^{2}$ \\ ${ }^{1}$ Institute of Biology, Odense University, Campusvej 55, DK-5230 Odense M, Denmark \\ ${ }^{2}$ Netherlands Institute for Sea Research, PO Box 59, 1790 AB Den Burg, Texel, The Netherlands
}

\begin{abstract}
Oxygen profiles, actual oxygen uptake and electron transport system activity (ETSA) were studied in 4 intertidal sediments at Texel, NW Netherlands. Organic carbon content ranged from 0.02 to $0.4 \%$ dry weight. Profiles of oxygen were recorded with a needle minielectrode and showed that oxygen was present down to $18 \mathrm{~mm}$ in the sandy beach sediment with low carbon content, whereas oxygen only penetrated down to 1 to $3 \mathrm{~mm}$ in the organically richer sediments. Measured oxygen uptake ranged from 395 to $2315 \mu \mathrm{mol} \mathrm{O} \mathrm{O}_{2}^{-2} \mathrm{~h}^{-1}$ and exceeded oxygen uptake estimated on basis of molecular diffusion by 1.4 to 3.2 times. The difference between the 2 methods for measuring oxygen uptake indicates that bottom fauna activity significantly contributes to the sediment-water exchange of oxygen. The ETSA varied from 0.02 to $0.81 \mu \mathrm{mol} \mathrm{O} \mathrm{O}^{-1} \mathrm{~h}^{-1}$ The ETSA at the sediment surface was positively correlated to sediment oxygen uptake. Neither ETSA nor oxygen uptake showed correlation to organic carbon or nitrogen content in the sediment.
\end{abstract}

\section{INTRODUCTION}

The measurement of sediment community respiration constitutes an important part of a large number of studies concerning benthic metabolic processes and the turnover of organic matter in sediments (e.g. Pamatmat 1968, Jørgensen 1977, Hargrave \& Phillips 1981, van Es 1982, Andersen \& Hargrave 1984, de Wilde et al. 1984). In these studies the oxygen uptake was measured by enclosing a part of the sediment surface in cores or bell jars and following the decrease in the oxygen concentration of the overlying water.

The use of the oxygen microelectrode in recent years has provided a possibility for estimating the oxygen flux on the basis of the oxygen concentration gradient at the sediment surface (Jørgensen \& Revsbech 1985, Lindeboom et al. 1985, Reimers \& Smith 1986). Helder \& Bakker (1985) showed that the needle minielectrode could be used instead of the microelectrode for recording oxygen profiles more than a few mm deep.

Another approach for estimating community metabolism is to measure biochemical activity. Christensen \& Packard (1977), Vosjan \& Olańczuk-Neyman (1977) and Pamatmat et al. (1981) measured electron transport system activity (ETSA) in marine sediments.
The ETSA gives a potential respiratory enzyme activity and thus includes both aerobic and anaerobic respiration processes (e.g. sulfate and nitrate respiration).

The purpose of the present investigation was to compare sediment oxygen uptake rates in sediment cores, estimated on the basis of oxygen gradients recorded with minielectrodes, with the measured oxygen uptake in the laboratory from the water above the sediment. Furthermore, we attempted to establish a relationship between the sediment oxygen uptake and the potential activity measurement of ETSA. The investigation was made on 4 sediments with different content of organic matter to study how this parameter influenced the metabolic activity.

\section{MATERIALS AND METHODS}

Localities and sampling. The investigation was carried out in 1985 on coastal sediments from 4 localities on the island Texel, NW Netherlands. Hoornderslag on the North Sea coast is a sandy beach sediment. The other 3 stations are on the Wadden Sea coast. Mokbaai 1 is at the mouth of a bay, whereas Mokbaai 2 is at the head of the bay. The Oost station is 
in a large shallow water area. All stations had sandy sediments with Hoornderslag as the coarsest and Oost as the finest. The sediments were intertidal and usually emerged for about $4 \mathrm{~h}$ of each tidal period.

The sediments were usually sampled about $3 \mathrm{~h}$ after high tide at $0.5 \mathrm{~m}$ depth. Undisturbed samples were taken with Plexiglas tubes ( $30 \mathrm{~cm}$ long, $5.2 \mathrm{~cm}$ diam.) and with 6 to $7 \mathrm{~cm}$ of overlying water. Field temperature was measured on the sediment surface at each sampling. The cores were brought to the laboratory within $0.5 \mathrm{~h}$ after sampling and placed in a thermostated room. The mean difference between the field temperature and the thermostated room was $2.7 \mathrm{C}^{\circ}$.

Oxygen profiles. Oxygen concentration in the sediment and in the overlying water was measured with a needle minielectrode $(2.5 \mathrm{~cm}$ long, $0.7 \mathrm{~mm}$ o.d., Diamond Electro-Tech) covered with a DePeX membrane. The minielectrode was connected to a picoammeter (Keithly 480) and mounted on an electrically driven micromanipulator using a calomel electrode as a reference. The measurements were carried out according to Helder \& Bakker (1985) without stirring of the overlying water. The molecular diffusion flux of oxygen to the sediment was estimated according to Jørgensen \& Revsbech (1985) on the basis of the oxygen gradient in the diffusive boundary layer in the water above the sediment using Fick's first law of diffusion:

$$
\mathrm{J}=\mathrm{D} \times\left(\Delta\left[\mathrm{O}_{2}\right] / \Delta \mathrm{Z}\right)
$$

where $\mathrm{J}=$ flux; $\mathrm{D}=$ molecular diffusion coefficient $\left(\mathrm{D}=2.0 \times 10^{-5} \mathrm{~cm}^{-2} \mathrm{~s}^{-1}\right.$ for $\mathrm{O}_{2}$ at $20^{\circ} \mathrm{C}$; Broecker \& Peng 1974): D was modified for temperature according to the Stokes-Einstein relation (Li \& Gregory 1974); $\Delta\left[\mathrm{O}_{2}\right]$ is the $\mathrm{O}_{2}$ gradient in the diffusive boundary layer; $\Delta \mathrm{Z}$ is the thickness of the boundary layer.

Oxygen uptake was determined by measuring oxygen concentrations in the water above the sediment in the cores at the beginning and end of a dark incubation period. Oxygen concentration was measured by an oxygen electrode (Radiometer Blood Gas Analyser). The oxygen concentration did not decrease below $80 \%$ of air saturation during the incubations. A magnetic stirrer mixed the overlying water during the incubations.

Electron transport system activity (ETSA). Sediment samples ( $5 \mathrm{~g}$ wet weight) from different depths of 3 parallel cores were weighed, mechanically homogenized (Model MSK, Braun-Melsungen) in $25 \mathrm{ml}$ $0.1 \mathrm{M}$ phosphate buffer and centrifuged. ETSA was measured on triplicate samples of the supernatant at $20^{\circ} \mathrm{C}$ according to Olańczuk-Neyman \& Vosjan (1977). Macrofauna was excluded from the measurements.

Carbon and nitrogen content. Two cores from each station were sectioned with depth for carbon and nitro- gen analysis and 2 to 3 measurements were made on each segment. Organic carbon and total nitrogen was determined on dried $\left(105^{\circ} \mathrm{C}\right)$ samples on a CHN-Analyser (Hewlett-Packard 185B). The sediment samples were acidified with $1 \mathrm{~N} \mathrm{HCl}$ before the organic carbon determination and corrections were made for weight increases after acidification (van Iperen \& Helder 1985).

\section{RESULTS}

The stations were selected to give a variation in organic matter content and thus probably also a range in metabolic activity. The organic carbon content varied from 0.02 to $0.4 \%$ of dry weight (Fig. 1). Oost and Mokbaai 2 showed a maximum at 0.5 to 1 and 1 to $2 \mathrm{~cm}$ depth, respectively, below which the organic carbon content decreased with depth. Hoornderslag and Mokbaai 1 showed the lowest carbon content, slightly decreasing with depth. The total nitrogen content of the sediment roughly followed the pattern of organic carbon. The nitrogen concentration in the Hoornderslag sediment was below the detection limit. The carbon to nitrogen ratio for all depths was: for Oost, 7.62 (SD 0.93); Mokbaai 1, 6.78 (SD 0.92); Mokbaai 2, 7.03 (SD 0.44).

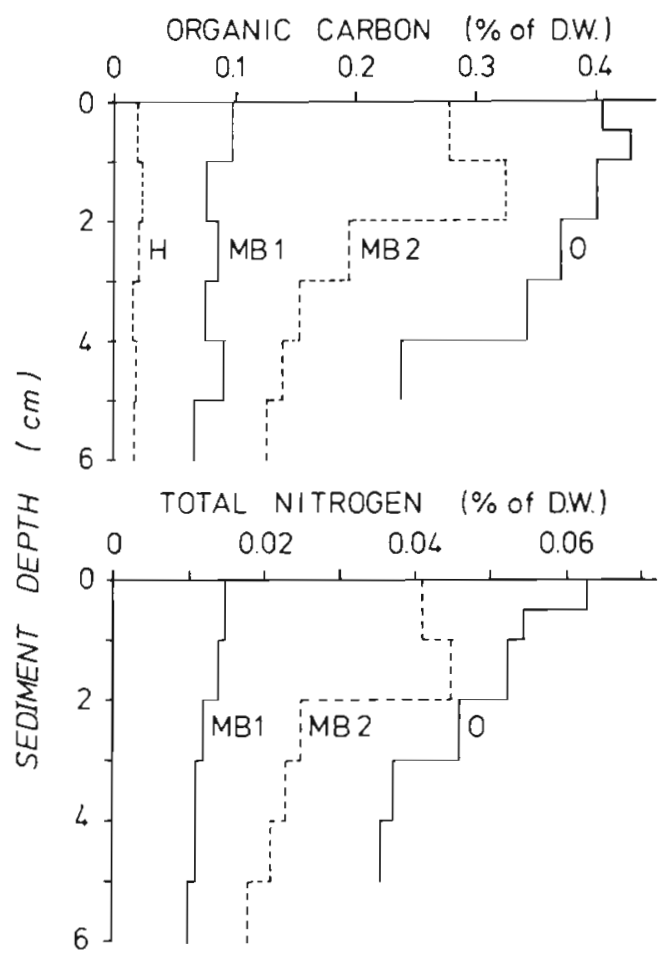

Fig. 1. Vertical profiles of organic carbon and total nitrogen content in 4 intertidal sediments. H: Hoornderslag; $M B 1$ : Mokbaai 1; MB 2: Mokbaai 2; O: Oost). Profiles represent means of 2 parallel cores (differences $<10 \%$ of the mean) with 2 or 3 measurements on each segment 


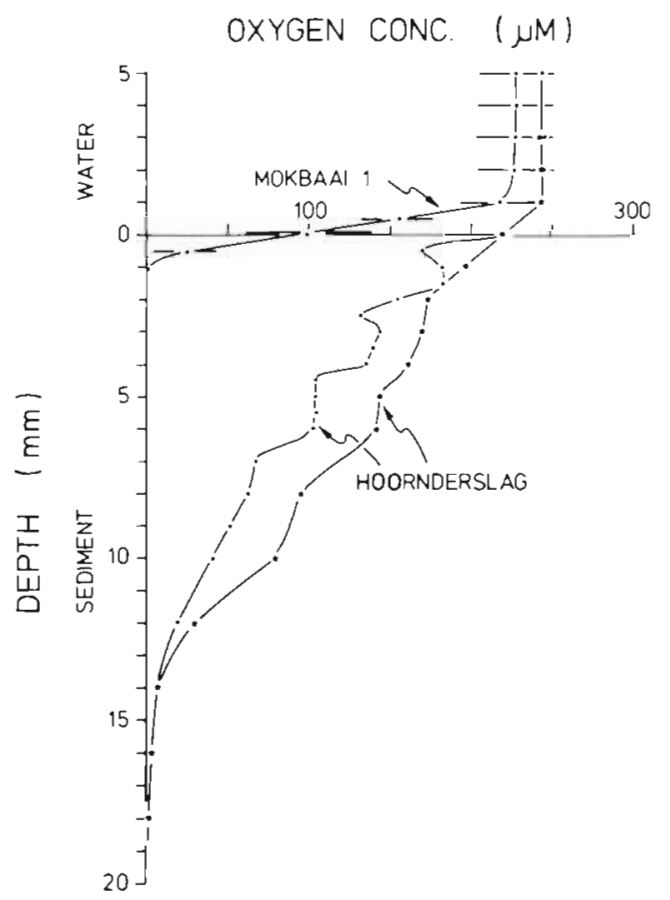

Fig. 2. Oxygen profiles from an exposed sandy beach sediment (Hoornderslag) compared with a representative profile from a more organic rich, sheltered bay sediment (Mokbaai 1, mean of 4 cores, horizontal bars indicate range)

The measurements of sediment oxygen concentration showed that oxygen in general only penetrated down to 1 to $3 \mathrm{~mm}$ depth in the Oost and Mokbaai sediments, whereas oxygen was recorded down to $18 \mathrm{~mm}$ depth in the beach sediment from Hoornderslag (Fig. 2). The fluctuations in the oxygen profiles in the Hoornderslag sediment were probably effects of the sand grains. The oxygen gradient already started in

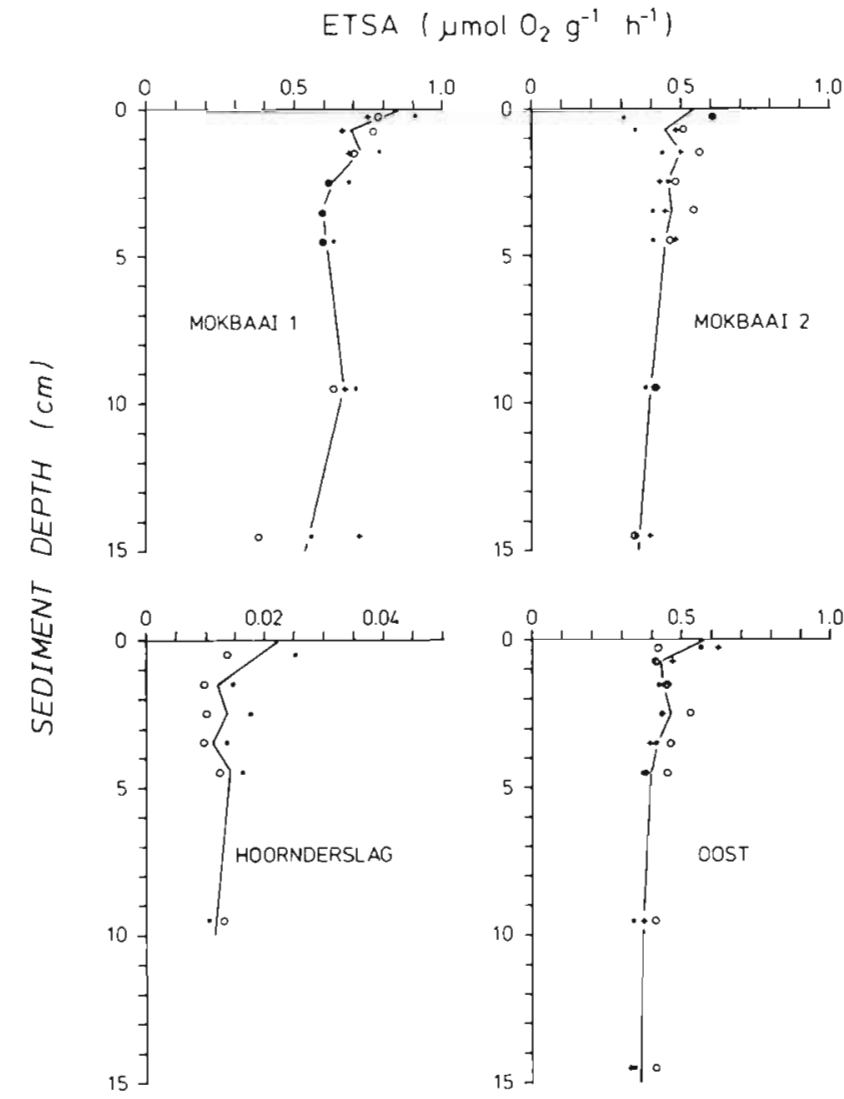

Fig. 3. Vertical profiles of ETSA in 4 intertidal sediments. Profiles are drawn through mean values. Symbols indicate individual cores

the boundary layer in the water above the sediment surface due to lack of stirring during the oxygen profile measurements. The flux of oxygen to the sediment due to molecular diffusion was estimated on the basis of

Table 1. Comparison between estimated and measured sediment oxygen uptake in 4 different sediments. Mean values \pm 1 SD, $\mathrm{n}=4$ for estimated flux and 8 for measured flux

\begin{tabular}{|c|c|c|c|c|c|}
\hline Locality & Date & $\begin{array}{c}\text { Temperature } \\
\left({ }^{\circ} \mathrm{C}\right)\end{array}$ & $\begin{array}{l}\text { Estimated flux } \\
\qquad(\mu \mathrm{mol}\end{array}$ & $\begin{array}{l}\text { Measured flux } \\
\left.\mathrm{n}^{-2} \mathrm{~h}^{-1}\right)\end{array}$ & Meas./Est. \\
\hline Hoornderslag & $\begin{array}{l}19 \text { Jun } \\
21 \text { Jun } \\
25 \text { Jun } \\
13 \text { Aug }\end{array}$ & $\begin{array}{l}20.0 \\
20.0 \\
13.7 \\
20.0\end{array}$ & $\begin{array}{r}- \\
171^{-}\end{array}$ & $\begin{array}{c}673 \pm 187 \\
727 \pm 253 \\
395 \pm 172 \\
-\end{array}$ & $\begin{array}{l}- \\
- \\
- \\
-\end{array}$ \\
\hline Mokbaai 1 & $\begin{array}{c}28 \mathrm{Jun} \\
1 \mathrm{Jul}\end{array}$ & $\begin{array}{l}13.6 \\
13.6\end{array}$ & $\begin{array}{l}841 \pm 170 \\
990 \pm 127\end{array}$ & $\begin{array}{l}1609 \pm 536 \\
1387 \pm 181\end{array}$ & $\begin{array}{l}1.9 \\
1.4\end{array}$ \\
\hline Mokbaai 2 & $17 \mathrm{Jul}$ & 17.7 & $622 \pm 320$ & $1924 \pm 371$ & 3.1 \\
\hline Oost & $\begin{array}{l}29 \text { Jul } \\
5 \text { Aug } \\
5 \text { Aug }\end{array}$ & $\begin{array}{l}22.0 \\
20.0 \\
20.0\end{array}$ & $\begin{array}{c}729 \pm 69 \\
- \\
-\end{array}$ & $\begin{array}{r}2315 \pm 718 \\
1230 \pm 375 \\
242 \pm 32^{b}\end{array}$ & $\begin{array}{c}3.2 \\
- \\
-\end{array}$ \\
\hline
\end{tabular}




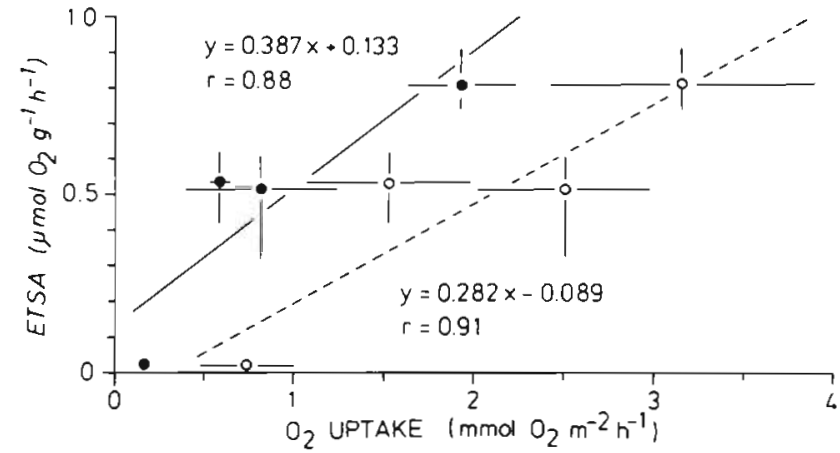

Fig. 4. Relation between ETSA and (O) measured and (•) estimated oxygen uptake. Oxygen uptake rates were modified to $20^{\circ} \mathrm{C}$ assuming a $Q_{10}$ of 3.2 . Horizontal bars indicate $\pm 1 \mathrm{SD}$, vertical bars indicate range

this gradient (Table 1). The estimated flux varied from 171 (Hoornderslag) to $990 \mu \mathrm{mol} \mathrm{O} \mathrm{O}_{2} \mathrm{~m}^{-2} \mathrm{~h}^{-1}$ (Mokbaai 1).

The directly measured oxygen uptake from the overlying water was higher than the estimated molecular diffusive flux. The measured oxygen flux varied from 395 (Hoornderslag) to $2315 \mu \mathrm{mol} \mathrm{O} \mathrm{m}^{-2} \mathrm{~h}^{-1}$ (Oost) (Table 1). This gives ratios between measured and estimated fluxes of 1.4 to 3.2 . For a comparison between stations the oxygen uptake rates have to be modified for the effect of different temperatures during the incubations. Jørgensen (1977) and Andersen \& Hargrave (1984) found $Q_{10}$ values of 3.2 and 2.46 to 3.97 (mean 3.2), respectively, for oxygen uptake in coastal marine sediments. The following rates were obtained after conversion to $20^{\circ} \mathrm{C}$ using a $Q_{10}$ of 3.2 : Hoornderslag, 0.67 to 0.82 ; Oost, 1.23 to 1.84 ; Mokbaai 2, 2.51; Mokbaai 1, 2.92 to $3.39 \mathrm{mmol} \mathrm{O}_{2} \mathrm{~m}^{-2} \mathrm{~h}^{-1}$. In one of the experiments on the Oost sediment, oxygen uptake was recorded for both unpoisoned and formalin-poisoned cores. Oxygen uptake in the formalin-poisoned cores is a measure of the oxidation of reduced substances that diffuse to the sediment surface when microbial and animal activity is stopped. This oxygen uptake was $42 \%$ of the estimated diffusive flux of oxygen to the sediment and $20 \%$ of the total oxygen uptake in cores with living organisms.

The ETSA was in general highest at the sediment surface and decreased with depth (Fig. 3). However, the rates at $15 \mathrm{~cm}$ depth (Hoornderslag $10 \mathrm{~cm}$ ) were still 61 to $69 \%$ of the sediment surface rates. The highest rates were obtained in Mokbaai 1 sediment (0.81), the lowest in the Hoornderslag sediment $\left(0.02 \mu \mathrm{mol} \mathrm{O} \mathrm{Og}^{-1} \mathrm{~h}^{-1}\right)$. The Oost and Mokbaai 2 sediments showed an intermediate rate of $0.53 \mu \mathrm{mol} \mathrm{O}_{2}$ $\mathrm{g}^{-1} \mathrm{~h}^{-1}$. ETSA showed significant positive correlations with measured and estimated oxygen uptake after modification of oxygen uptake rates to $20^{\circ} \mathrm{C}$ (t-test, $\mathrm{p}<0.05$ ) (Fig. 4). Neither ETSA nor oxygen uptake rates were correlated to the sediment organic carbon or nitrogen content.

\section{DISCUSSION}

Oxygen penetration in the Hoornderslag sediment was high $(18 \mathrm{~mm})$ compared with the other stations ( 1 to $3 \mathrm{~mm}$ ) and with other studies on coastal marine sediments. Thus, Jørgensen \& Revsbech (1985) showed pentration depths of less than $2 \mathrm{~mm}$ in a shallow Limfjorden sediment (water depth $0.5 \mathrm{~m}$ ) and about $2 \mathrm{~mm}$ in Aarhus Bay sediment (water depth $20 \mathrm{~m}$ ). In the deeper Skagerrak (water depth 208 to $387 \mathrm{~m}$ ) Helder \& Bakker (1985) found penetration depths of 8 to $11 \mathrm{~mm}$. The relatively high oxygen penetration in the sandy beach sediment is an effect of the very low organic matter content and the infiltration of water due to wave exposure and tides. However, Rutgers van der Loeff (1981) found that in sandy tidal flat sediments waveinduced percolation rarely contributes significantly to diffusion in the sediment. McLachlan et al. (1985) found a horizontal percolation of water in a tidal sandy beach sediment. This implies that pore water in cores from the lower part of the tidal area may have been subject to oxygen consumption during earlier horizontal transport from higher parts of the beach. Although oxygen penetration in the Hoornderslag beach sediment is relatively high when compared with our other stations, it is very restricted when compared with $\mathrm{NE}$ Atlantic deep-sea sediments (4200 to $4800 \mathrm{~m}$ depth) with organic carbon content about $0.2 \%$. In these NE Atlantic sediments oxygen penetration was $\gg 20 \mathrm{~cm}$ (Rutgers van der Loeff \& Lavaleye 1986). The difference in oxygen penetration between these 2 types of sediment with comparable organic carbon content is probably associated with a much higher turnover rate of easily degradable organic carbon in the Hoornderslag sediment compared to the NE Atlantic sediments. The oxygen profiles from the Hoornderslag sediment represent the first measurements on coarse sand beach sediment. The measurements were only made possible by the rugged stainless steel minielectrode covered with a hard membrane. During initial measurements, glass microelectrodes broke in the coarse sediment. The measured flux rates of oxygen to the sediment exceeded the estimated molecular diffusion flux rates by a factor of 1.4 to 3.2 . This is probably due both to effects of the benthic fauna (bioturbation) and to differences in stirring of the water in the 2 methods. Boynton et al. (1981) found that sediment oxygen uptake was positively correlated with stirring of the water and Jørgensen \& Revsbech (1985) found that the thickness of the diffusive boundary layer decreased with increasing flow velocity. In our study the cores were stirred 
until immediately before - but not during - measurements of the oxygen profiles. Therefore, we cannot exclude that some of the differences between measured and estimated oxygen flux were caused by differences in mixing of the water. However, Kristensen (1985) found that bioturbation by Nereis virens increased oxygen uptake by $74 \%$ compared to sediment without Nereis. Jørgensen \& Revsbech (1985) also demonstrated high spatial heterogeneity and instability of the oxygen microgradients at the sediment surface due to macro- and meiofaunal activity in a shallow water sediment. Therefore, we suggest that flux rates based on oxygen microgradients recorded from areas of sediment surface with no faunal activity to a high degree reflect microbial metabolism whereas directly measured oxygen uptake from the overlying water also includes fauna metabolism. Unfortunately, faunal composition and density was not recorded in this study.

In contrast to our findings, Reimers \& Smith (1986), in a study on deep-sea sediment (water depth $3700 \mathrm{~m}$ ), estimated oxygen flux based on oxygen gradients in the same order as the directly measured oxygen uptake. They concluded that bottom fauna activity was relatively unimportant for determining oxygen fluxes in the studied deep-sea sediment.

Oxygen uptake rates found in this study 10.40 to $2.32 \mathrm{mmol} \mathrm{O}_{2} \mathrm{~m}^{-2} \mathrm{~h}^{-1}$ ) are within the range of published values $\left(0.13\right.$ to $\left.6.12 \mathrm{mmol} \mathrm{O}_{2} \mathrm{~m}^{-2} \mathrm{~h}^{-1}\right)$ from coastal marine sediments (Jørgensen 1977, Revsbech et al. 1980, Hargrave \& Phillips 1981, van Es 1982, Andersen \& Hargrave 1984).

A comparison of the oxygen uptake with the sediment organic carbon or nitrogen content showed no correlations. Hargrave \& Phillips (1977), in a review on determining factors for oxygen uptake of microbial communities on solid surfaces, also found no simple relation between respiration and organic content per unit area. Similarly, van Es (1982) found that the amount of organic carbon in the sediment was of less importance for community respiration than temperature and viable bacteria. An explanation of the relationship between oxygen uptake and organic matter in the sediment probably requires a more detailed analysis of different pools of organic matter and their degradability

One of the aims of this study was to find a relationship between ETSA and actual respiratory activity. We found that ETSA at the sediment surface was correlated to the actual sediment oxygen uptake rate. However, direct comparison of the rates is difficult because oxygen uptake was recorded on an areal basis while ETSA was recorded on a weight basis. Recalculation of ETSA to per unit area involves integration of ETSA at the different depths from the sediment surface to the depth where it is zero. However, our results showed a high activity even at $15 \mathrm{~cm}$ depth; Vosjan \& OlańczukNeyman (1977) found activity in $35 \mathrm{~cm}$ depth in sediments similar to ours. The high ETSA at these depths indicates a considerable anaerobic respiratory metabolism because oxygen only penetrated down to 1 to $18 \mathrm{~mm}$. Vosjan \& Olańczuk-Neyman (1977) directly compared ETSA and potential oxygen consumption in sediment samples down to $35 \mathrm{~cm}$. The 2 measurements were not correlated because the oxygen consumption showed a large variation. This may have been caused by abiotic oxygen consumption by reduced substances such as sulfide. The ETSA rates found by Vosjan \& Olańczuk-Neyman (1977) were of the same order as those found in the present study, except for the low rates we recorded from Hoornderslag.

In similarity with the oxygen uptake rates the ETSA was not correlated to the organic carbon or nitrogen content. Christensen \& Packard (1977), in contrast, found a close correlation between ETSA and protein in sediments off NW Africa. Pamatmat et al. (1981) studied the relationship between ETSA, ATP and heat production in subtidal sediment and beach sediment. ETSA was only correlated with ATP in the subtidal sediment and with heat production in beach sediment.

In the present investigation we studied 4 different types of sediments and, although we found a correlation between ETSA and oxygen uptake by the sediment, we suggest further studies on a greater variety of sediments. In addition we think that the use of a conservative tracer in connection with the 2 methods for measuring oxygen flux would be useful for evaluating the effects of bioturbation.

Acknowledgements. We thank Mr Ove Larsen for assistance with field and laboratory work and Drs. J. Vosjan and J. F. Bakker for help with measurements of ETSA and oxygen gradients. This research was in part supported by grant No. 11-5298 from the Danish Natural Science Research Council to F. $\varnothing$. Andersen.

\section{LITERATURE CITED}

Andersen, F. Ø., Hargrave, B. T. (1984). Effects of Spartina detritus enrichment on aerobic/anaerobic benthic metabolism in an intertidal sediment. Mar. Ecol. Prog. Ser. 16: 161-171

Boynton, W. R., Kemp, W. M., Osborne, C. G., Kaumeyer, K. R., Jenkins, M. C. (1981). Influence of water circulation rate on in situ measurements of benthic community respiration. Mar. Biol. 65: 185-190

Broecker, W. S., Peng, T.-H. (1974). Gas exchange rates between air and sea. Tellus 26: 21-35

Christensen, J. P., Packard, T. T. (1977). Sediment metabolism from the northwest African upwelling system. Deep Sea Res. 24: 331-343

Es, F. B. van (1982). Community metabolism of intertidal flats in the Ems-Dollard estuary. Mar. Biol. 66: 95-108 
Hargrave, B. T., Phillips, G. A. (1977). Oxygen uptake of microbial communities on solid surfaces. In: Cairns, J. (ed.) Aquatic microbial communities. Garland Publ., New York, p. 545--587

Hargrave, B. T., Phillips, G. A. (1981). Annual in situ carbon dioxide and oxygen flux across a subtidal marine sediment. Estuar. coast. Shelf Sci. 12: 725-737

Helder, W., Bakker, J. F. (1985). Shipboard comparison of micro- and minielectrodes for measuring oxygen distribution in marine sediments. Limnol. Oceanogr. 30 1106-1109

Iperen, J., van, Helder, W. (1985). A method for the determination of organic carbon in calcareous marine sediments. Mar. Geol. 64: 179-187

Jørgensen, B. B. (1977). The sulfur cycle of a coastal marine sediment (Limfjorden, Denmark). Limnol. Oceanogr. 22: 814-832

Jørgensen, B. B., Revsbech, N. P. (1985). Diffusive boundary layers and the oxygen uptake of sediments and detritus. Limnol. Oceanogr. 30: 111-122

Kristensen, E. (1985). Oxygen and inorganic nitrogen exchange in a Nereis virens (Polychaeta) bioturbated sediment-water system. J. coast. Res. 1: 109-116

Lindeboom, H. J., Sandee, A. J. J., Driessche, H. A. J. de K.-v. d. (1985). A new bell jar/microelectrode method to measure changing oxygen fluxes in illuminated sediments with a microalgal cover. Limnol. Oceanogr. 30: 693-698

Li, Y. H., Gregory, S. (1974). Diffusion of ions in sea water and in deep-sea sediments. Geochim. cosmochim. Acta 38: 703-714

McLachlan, A., Eliot, I. G., Clarke, D. J. (1985). Water filtration through reflective microtidal beaches and shallow sublittoral sands and its implications for an inshore ecosystem in Western Australia. Estuar. coast. Shelf Sci. 21: $91-104$
Olańczuk-Neyman, K. M., Vosjan, J. H. (1977). Measuring respiratory electron-transport-system activity in marine sediment. Neth. J. Sea Res. 11: 1-13

Pamatmat, M. M. (1968). Ecology and metabolism of a benthic community on an intertidal sand flat. Int. Revue ges. Hydrobiol. 53: 211-298

Pamatmat, M. M., Graf, G., Bengtsson, W., Novak, C. S. (1981). Heat production, ATP concentration and electron transport activity of marine sediments. Mar. Ecol. Prog. Ser. 4: 135-143

Reimers, C. E., Smith, Jr., K. L. (1986). Reconciling measured and predicted fluxes of oxygen across the deep sea sediment-water interface. Limnol. Oceanogr. 31: 305-318

Revsbech, N. P., Sørensen, J., Blackburn, T. H., Lomholt, J. P. (1980). Distribution of oxygen in marine sediments measured with microelectrodes. Limnol. Oceanogr. 25: $403-411$

Rutgers van der Loeff, M. M. (1981). Wave effects on sediment-water exchange in a submerged sand bed. Neth. J. Sea Res. 15: 100-112

Rutgers van der Loeff, M. M., Lavaleye, M. S. S. (1986). Sediments, fauna and the dispersal of radionuclides at the N.E. Atlantic dumpsite for low-level radioactive waste. In: Report of the Dutch DORA program. Netherlands Institute for Sea Research, Texel, p. 14-77

Vosjan, J. H., Olańczuk-Neyman, K. M. (1977). Vertical distribution of mineralization processes in a tidal sediment. Neth. J. Sea Res. 11: 14-23

Wilde, P. A. W. J. De, Berghuis, E. M., Kok, A. (1984). Structure and energy demand of the benthic community of the oyster ground, central North Sea. Neth. J. Sea Res. 18: 143-159

This article was submitted to the editor; it was accepted for printing on February 16, 1987 